International Journal of Child, Youth and Family Studies (2011) 3 \& 4: 385-409

\title{
IMMEDIATE RESPONSE: ADDRESSING ANTI-NATIVE AND ANTI-BLACK RACISM IN CHILD WELFARE
}

\author{
Gordon Pon, Kevin Gosine, and Doret Phillips
}

\begin{abstract}
Anti-oppression emerged in the 1990s as a perspective for challenging inequalities and accommodating diversity within the field of social work, including child welfare in Canada. Using the concepts of white supremacy, antiBlack, and anti-Native racism in conjunction with the notion of the exalted national subject (Thobani, 2007), we contend that any understanding of the overrepresentation of Aboriginal and Black children in the care of child welfare services must be located within the wider narrative of white supremacy that has underpinned the formation of the post-war welfare state. This overrepresentation highlights the need to shift from anti-oppression to critical race feminism and anti-colonialism perspectives in order to address more effectively anti-Black and anti-Native racism and the economy of child welfare.
\end{abstract}

Keywords: child welfare, critical race feminism, anti-colonialism, antioppression, anti-racism, disproportionality

Acknowledgement: The authors wish to thank two anonymous reviewers for their constructive feedback on this manuscript. This article was presented at the annual meeting of the Canadian Association of Social Work

Education, Fredericton, New Brunswick, Canada, June 2011.

Address correspondence to: Gordon Pon, Ph.D., School of Social Work, Ryerson University, 350 Victoria Street, Toronto, Ontario, M5B 2K3

E-Mail: g2pon@ryerson.ca

Gordon Pon, Ph.D., is an Associate Professor in the School of Social Work, Ryerson University, Toronto, Ontario, Canada.

Kevin Gosine, MSW, Ph.D., is an Associate Professor in the Department of Sociology, Brock University, St. Catharines, Ontario, Canada.

Doret Phillips, MSW, RSW, is a Social Worker who practices from a critical feminist and anti-racist framework. She has extensive work experience in child welfare, violence against women initiatives, and counselling parents and children. 
International Journal of Child, Youth and Family Studies (2011) 3 \& 4: 385-409

While anti-oppression perspectives in social work are increasingly championed as a progressive and liberatory social justice response, we will argue that they are limited in their capacity to address racism in the child welfare system. Instead, we assert that critcial race feminism (Razack, Smith, \& Thobani, 2010) and anti-colonialism are much more critical and transformative approaches to social work in comparison to anti-oppression. As anti-oppression perspectives become increasingly mainstreamed ${ }^{\mathrm{i}}$ (McLaughlin, 2005), its proponents seldom discuss difficult topics such as white supremacy, anti-Black and anti-Native racism, particularly in relation to child welfare. Conversely, critical race feminism scholars such as Sunera Thobani (2007) argue that the overrepresentation of Aboriginal $^{\text {ii }}$ and Black children in the care of the Canadian child protection system is inseparable from the history of white supremacy in Canada.

In what has become known as the "Sixties Scoop," Canadian child welfare authorities in the 1960s began removing high numbers of Indigenous children from their parents, extended family, and communities and placing them with non-Indigenous families (Baskin, 2006; Blackstock and Trocmé, 2004; Strega, 2007; Thobani, 2007). This persisted into the 1980s. Of the approximately 76,000 children and youth living in out-of-home care in Canada during the years 2000 to 2002, about 40\% were Aboriginal (Farris-Manning \& Zandstra, 2003). More recently, Strega and Esquao (2009) estimate that 25,000 of the 65,000 , or $38 \%$ of children in out-of-home care in Canada are Aboriginal. However, Aboriginal children comprise only 5\% of the children in Canada (Trocmé, Knoke, \& Blackstock, 2004). In Manitoba, a Canadian province, nearly 80\% of the children living in out-of-home care are Aboriginal (see Trocmé et al., 2004).

Aboriginal youth aged 0-19 represent less than 3\% of the total child population in Ontario, Canada's largest province, but $14.4 \%$ of the number of Aboriginal children in care (Ontario Association of Children's Aid Societies, 2008). Today there are three times as many Aboriginal children in care as compared to the height of the Indian residential schools (Mandell, Clouston Carlson, Fine, \& Blackstock, 2007).

Black children and youth are also overrepresented in the child welfare system in Canada. The Child Welfare Anti-Oppression Roundtable (2009), an initiative which includes representation of almost half of the 52 child welfare agencies in Ontario, notes that in an urban Ontario city, Black youth represent $65 \%$ of the children in care, despite the fact that the Black population in this urban centre totals only $8 \%$.

In this paper, we use a critical race feminism approach (Razack et al., 2010) to understand this overrepresentation as being implicated in Canada's "master narrative of the nation” (Thobani, 2007, p. 4), which is inseparable from a history of white supremacy that was central to the formation of the Canadian nation and the rise of the post-war welfare state. This post-structural approach views power as diffuse, contradictory, fragmented, and implicated in what Foucault (1980) referred to as discourse. According to Foucault, power and subjectivity are inseparable in that the individual is at once both subjected to rule by entities such as government and is also an active agent or subject in 
the creation of who they are (Prado, 2000). The discourse of the national subject is, according to Thobani, one that heralds this individual to be a venerated and exalted responsible citizen who for the most part is compassionate and caring, much like the welfare state itself. The exalted national subject is depicted as having to contend against the intrusions and threats of the racial Other, who jeopardize the collective welfare and prosperity of the nation (Thobani, 2007). Simultaneously, Aboriginal and racialized immigrant families were historically excluded from access to the provisions of the welfare state (Maiter, 2009; Thobani, 2007). We will argue that the contemporary overrepresentation of Aboriginal and Black children in care is implicated in this master narrative of nation. We further argue that anti-colonialism and critical race feminism, and not anti-oppression, are the most pressing and promising frameworks for theorizing and responding to the overrepresentation of Black and Indigenous children in care.

Affirming the feminist anti-racist and anti-colonial emphasis on self-reflexivity and critical awareness of subject location in relation to scholarly work (see Lawrence \& Dua, 2005), we briefly highlight the differing and varied subject positions and experiences that we bring to this collaboration. Gordon Pon is a Chinese Canadian, male, who has over five years of experience in front line child welfare work as a Children Services Worker, Intake Worker, and Family Services Worker. He is heterosexual, ablebodied, middle class, and a professor of social work in a large Canadian university. Kevin Gosine identifies as an able-bodied, heterosexual, Canadian-born, racialized middle-class professor of Sociology. He locates himself in this middle-class position after growing up in the lower working-class community of Regent Park located in downtown Toronto, Canada. Doret Phillips is a Black Canadian, female, anti-racism activist practitioner, who has over nine years of front line experience in child welfare as a Family Services Worker. She is heterosexual, now middle class, and holds a graduate degree in social work.

\section{White Supremacy, Anti-Black Racism, and the Exalted National Subject}

The etiology of the overrepresentation of Aboriginal and Black children in care of the child welfare systems of Canada and other Anglo-American nations (Strega \& Esquao, 2009) is debated among researchers. While some scholars argue that colonialism and racism explain this overrepresentation (Blackstock \& Trocmé, 2004; Chand, 2000; Clarke, 2010; Dumbrill, 2003; Gosine \& Pon, 2010; Roberts, 2002), others assert that there is no compelling evidence that race alone contributes substantially to child welfare decision making (Barth, Miller, Green, \& Baumgartner, 2001). Barth et al. (2001) argue that the disproportionality of African-Americans involved with child welfare services is linked to African-American children being at higher risk for needing child protection services, especially in light of high incarceration and death rates associated with AfricanAmericans. Similarly, Tilbury and Thoburn (2009) caution that racial disproportionality may not necessarily be negative, especially if some Aboriginal and Black families benefit from child welfare involvement.

We assert that the contemporary racial disproportionality in child welfare is inseperable from the historical exigencies of race, class, and gender divisions that were central to the very formation of the Canadian settler nation state. Ng (1993) argues that 
race, like class, gender, and sexual orientation, is to be understood not "as categories designating different and separate domains of social life" (p. 50), but as concrete social relations that organize "how people define themselves and how they participate in social life” (p. 51). The discursive nature of the concept of race signals its fluid and shifting nature. Historically the concept of race emerged during modernity. Modernity is the time period beginning around the 15th century with the European "voyages of discovery" (Goldberg, 1993; Lawrence \& Dua, 2005) and is characterized by the subsequent colonization and genocide of Indigenous peoples throughout the world and later, the slavery of Africans. These colonial forays into vast "unconquered" lands with tremendous mineral wealth and natural resources gave rise to European expansionism that, fuelled by desires for profit maximization, quickly developed into capitalist industrialization (Bolaria \& Li, 1988). This, in turn, created a relentless European demand for raw materials, exploitation of natural resources, cheap (indentured) labour, and slavery (Bolaria \& Li, 1988).

Gilroy (1993) starkly describes modernity as a period of Western racial terror. The origins of the concept of race can be located within the Western European colonial and imperial expansion activities, particularly in the 17th century (Dei, 1996). The concept of race was deployed within an ideology that legitimized social relations involving the exploitation, domination, and annihilation of non-Western people and socially constructed the supremacy of the white race (Dei, 1996, 2008; Goldberg, 1993; Gilroy, 1993).

In the mid-18th century, modernity gave rise to a European intellectual history called the Enlightenment. Also known as the Age of Reason, this epoch which Hall (2007) described as the domination by the West of the "rest," saw the displacing of religion by science as the grounds of intellectual authority and cultural legitimacy. The Enlightenment also witnessed the emergence of independent scientific domains of anthropology and biology. From these domains emerged scientific racism which involved a classificatory order of racial groupings and socially constructed white Europeans as being the highest representatives of civilization (Banton, 1987; Gates, 1986; Goldberg, 1993). Scientific racism legitimized and justified the imperialization and colonization of "lesser" races and promoted the discourse that "it was the 'white man's burden' to brighten the dark continents with light” (Ching, 1998, p. 67).

It is vital to understand and contextualize this history of racism and colonialism when discussing the overrepresentation of Black and Aboriginal children in care. Lowe (1996) and Razack et al. (2010) observe a prevailing ontology of forgetting this history that characterizes nations such as Canada and the United States. This ontology involves forgetting the genocide of Aboriginal peoples (Baskin, 2006; Monture, 1995) and the history of white supremacy, racism, and Western imperialism which proved central to the formation and ascendancy of nations such as Canada and the United States (Lowe, 1996). Such acts of forgetting elide the slavery of African and Aboriginal peoples which was practiced by both the French and British in Canada for over two centuries (James et al., 2010). Moreover, this ontology of forgetting perpetuates the view of Canada as a fair and 
tolerant society, despite the reality of pervasive racism and sexism (Galabuzi, 2006; Henry \& Tator, 2010; Lawrence \& Dua, 2005).

Reflecting this ontology of forgetting is that despite the striking racial disproportionality, little is mentioned in the child welfare literature about anti-Black racism and white supremacy. However, these concepts offer a powerful way to understand this phenomenon of racial disproportionality in the Canadian child welfare system. The concept of anti-Black racism emphasizes the particular racism experienced by Black people in Canada, which is rooted in the history of slavery and the colonial period. Anti-Black racism calls attention to the specific laws and practices that led to the segregation in education, housing, and employment experienced by Black people in Canada (James et al., 2010). Anti-Native racism pertains to the distinct forms of racism and colonialism experienced by Native people in Canada. White supremacy refers to the policies and practices in settler societies and the exaltation of White people as national subjects, and the devaluation of racial "others" as threats to the security and prosperity of the nation (Thobani, 2007). As we have seen, the concept of white supremacy is rooted in the history of modernity and European colonialism. White supremacy, anti-Black and anti-Native racism are vital concepts for countering the ontology of forgetting and for transforming continued racism in contemporary Canadian society.

This history of settler nations such as Canada reveals social policies and practices that secured a white supremacist nation state along with a legacy replete with deadly relations with its racial Others (Razack et al., 2010). Thobani (2007, p. 42) notes that "Henry VII charged John Cabot with crossing the Atlantic 'to conquer, occupy and possess' the lands of 'heathens and infidels.'” She points further to the continuity of the genocidal violence practiced by the French and British via the violent colonization processes throughout the Americas, which included waging war against Indigenous societies, paying bounties for the scalps of Indigenous People, using "poisoned food and blankets contaminated with smallpox,...starvation, coercion, trickery and deception” (p. 42).

The Indian residential school system is a striking example of a deadly colonialism steeped in discourses of white supremacy (Henry \& Tator, 2010). The Indian residential schools were part of an education system that began in the 19th century which had the express purpose of solving the "Indian problem." In 1908 Frank Oliver, then Minister of Indian Affairs, explained that residential schools would "elevate the Indian from his condition of savagery” (as cited in Henry \& Tator, 2010, p. 103). The Assembly of First Nations has identified the residential school system as being implicated in cultural genocide (Henry \& Tator, 2010). The residential schools exacted genocide through sexual and physical abuse, purposeful spreading of smallpox, and the eventual death of $50 \%$ of the children in these schools (Henry \& Tator, 2010). Church records reveal that federal funding policies paid schools on a per capita basis, which fuelled the church's desire to maximize profit by having high enrollment numbers of Aboriginal children and refusing to send sick children home (Henry \& Tator, 2010). The generational traumatic impact of the residential schools is overwhelming and has marginalized generations of 
International Journal of Child, Youth and Family Studies (2011) 3 \& 4: 385-409

Aboriginal Peoples, both from the Canadian mainstream and within their own home environments (Henry \& Tator, 2010).

The genocidal racial violence in Canadian history is central to what Thobani (2007) describes as a process in settler societies whereby whites come to claim the status of the exalted national and all the rights and entitlements accompanying such claims to the nation. Citizenship and immigration laws were primary instruments through which whites attained the heralded status as national subject.

Racist immigration policies ensured the creation of a white national population that enjoyed an exalted national status and the full rights of citizenry, along with the access to resources that this permitted (Thobani, 2007). From 1867 to the 1970s immigration and naturalization laws distinguished white British and French people, and later other Europeans, as "preferred races” for integration into the nation (Thobani, 2007). The "non-preferred" races of immigrants were marked as strangers or sojourners, "an unwelcome intruder whose lack of Christian faith, inherent deviant tendencies, and unchecked fecundity all threatened the nation's survival” (Thobani, 2007, p. 75). The turning away from Canada of the ships called the Komagata Maru (1914) and St. Louis (1939), which carried Indian migrants and Jewish refugees respectively, highlight the racialized nature of Canadian immigration policies. Racist immigration laws such as the 1910 Immigration Act, legislated prohibitions on the grounds of race and became " "the principal instrument' for the 'Keep Canada White' policies” for the next 50 years (Thobani, 2007, p. 92). Other examples include the 1923 Chinese Immigration Act; Chinese Head Taxes of 1885, 1900, and 1903; and the Continuous Passage Requirement of 1908 (Bolaria \& Li, 1988).

The exaltation of white nationals coexisted with explicit racist and sexist discourses that were aimed at preventing non-white women from immigrating to Canada. The "women of the non-preferred races were constituted as morally degenerate, sexually depraved, and endowed with fecundity more animalistic than human. Keeping them out of the country was considered a special priority of immigration policies" (Thobani, 2007, p. 92). Indeed, prior to the 1960s few women from China and South Asia were allowed to immigrate to Canada. Single Black women were allowed entry as domestic workers, but were not permitted to be accompanied by their families (Thobani, 2007).

Even upon entry into Canada, members of the non-preferred races experienced racism and sexism in terms of naturalization laws. The Immigration Act of 1923 created three classes of citizens which were: (a) natural born, (b) naturalized, (c) those granted citizenship through certificate. Racism and sexism were evident in Section 10 of the Act that stipulated that applicants for a certificate of citizenship who were not fluent in English or French required a residency period of 20 years. Those fluent in French and English were required to have only five years of residency. But non-white immigrant women were the most likely of applicants not to be fluent in French or English. In this way the Act maintained and reproduced systemic racism and sexism (Thobani, 2007). 
International Journal of Child, Youth and Family Studies (2011) 3 \& 4: 385-409

In efforts on the part of nationals to appear less racist, and given the declining population growth and the exigencies of meeting labour market needs, the explicitly racist immigration laws were replaced with the point system in the Immigration Act of 1976-77 (Henry \& Tator, 2010; Thobani, 2007). This system allotted points to prospective immigrants based on factors such as education, profession, occupation, language, and skill levels. The point system shifted the processes of racism to more covert practices such as allocating fewer resources (immigration offices) in developing nations compared to developed ones, or allowing immigration officers to allot points on a discretionary basis for such things as personal suitability (Henry \& Tator, 2010). This discretionary power resulted in officers favouring male over female applicants (Thobani, 2007). By the time the point system was implemented, the national narrative of white supremacy had established the popular discourse of non-whites as "newcomers" or "immigrants" in Canada, despite the First Nations status of Aboriginal people, and the long-standing presence of Blacks and Asians in the settler nation (Thobani, 2007).

\section{The Welfare State and the Exalted National Subject}

Given the historical exclusion from citizenship rights experienced by Aboriginal and racialized people in Canada, Thobani (2007) observes that few historians have remarked on the impact of the developing welfare state on processes of racialization and national formation. She notes that the "welfare system reinforced citizenship as the mechanism organizing the racial hierarchy of the settler society” (pp. 107-108). Additionally, social entitlements of the nascent welfare state were not equitably accessible to Aboriginal and racialized immigrant families (Maiter, 2009).

Thobani (2007) asserts that the emergence of the post-war welfare state was in response to emerging labour unrest and the burgeoning women's movement. In order for nationals to appear to be sensitive to these movements, Canadian citizenship was expanded to include social entitlements to the welfare state. This expansion allowed the state to establish a perception that it was benevolent and well vested in representing the interests of all members of society, and not just the elites or its exalted national subjects (Thobani, 2007). Moreover, Thobani contends that the welfare state played a role in the master national narrative by constructing the exalted nationals as kind and compassionate.

In contrast to the welfare state's provision of care to Canadian families, Thobani argues that Aboriginal and immigrant families were regarded as threats to the nation's well-being. Concomitant with welfare provisions being provided to white Canadian families, Aboriginal families had been "marked for systematic destruction through the residential school system, which was maintained by the welfare state until the 1960s" (Thobani, 2007, p. 108). Similarly, the use of citizenship as a means to access many provisions of the nascent post-war welfare state precluded immigrant families, particularly immigrant women, from equal access. This is evidenced in the overtly racialized immigration and citizenship legislation that proliferated well into the 1970s (Henry \& Tator, 2010; Thobani, 2007). 
Even as Canadian immigration policies underwent liberalization in the 1970s in efforts to appear less racist, racism persisted by the way of making racialized immigrant women of the family class dependent on immigrant men, and thus not the nation (Thobani, 2007). Through immigration sponsorship regulations, sponsored immigrants and their families were denied access to the social rights of citizenship and access to social entitlements such as welfare state programs. As dependents of men, these women and their families were severely restricted in terms of access to social programs. This dynamic intensified the vulnerability of these women to abuse and exploitation within their homes and larger society, while also buttressing the national imagination's white supremacist stereotyping of non-white communities as being hyper-patriarchal, backwards, misogynist, and uncivilized (Razack, 2005).

The welfare state provisions made available to Aboriginal families significantly differed from the entitlements afforded the exalted white nationals. While the exalted white nationals were reaping the benefits of and entitlements to the nascent welfare state, state sanctioned intrusions into Aboriginal family and community life through the removing of Aboriginal children from their families and placement into residential schools continued well into the 1970s (Esquao \& Sinclair, 2009; Haig-Brown, 1988; Henry \& Tator, 2010).

In the 1960s, the welfare state became embodied or represented by the child protection system which gradually replaced the residential school system as the vehicle for carrying out nationalistic interests. During that time period, child welfare workers began apprehending Aboriginal children in disproportionately high numbers (Thobani, 2007). In what could be characterized as an "agent of colonization”, the child welfare system naturalized the removal of Aboriginal children by constructing Aboriginal women as "bad mothers" (Thobani, 2007, p. 122) and promoted the discourse of "mother-blame" (Strega, 2007). We believe Weaver's (1999) contention that "social workers must understand the atrocities of the indigenous holocaust in this country and the unresolved pain associated with it” (p. 221) applies equally to Canada. Henry and Tator (2010, p. 102) explain that "like the residential school system, the child welfare system in the 1960s and 1970s was designed to ensure institutionalized assimilation.”

This history of the welfare state is critical for understanding the current overrepresentation of Aboriginal and Black children in care because, as Thobani asserts, there is in operation a master narrative of nation that has historically venerated and exalted the responsible, white, citizen who, for the most part, is "compassionate, caring, and committed to the values of diversity and multiculturalism” (Thobani, 2007, p. 4). The exalted white national is in direct contradistinction to the Aboriginal and racial Other, who threaten the collective welfare and prosperity of the nation (Thobani, 2007). The child welfare system, we argue, has played and continues to play a significant role in this national narrative. 
International Journal of Child, Youth and Family Studies (2011) 3 \& 4: 385-409

\section{The Welfare State, White Supremacy, and the Role of White Women Social Workers}

Like a simulacrum of compassion and care, the welfare state from its inception has been unable to escape its modernist foundations and the master national narrative that exalted the national subject, while continuing the colonialist imperatives to "kill the Indian" and contain the threats to the national imagination signified by the racial Other. Most importantly, in relation to social work, Thobani (2007) argues that the rise of the post-war welfare state established a new positioning and valuation of white women within the master national narrative. White women social workers, particularly those employed by child welfare agencies, embodied the feminized virtues of care and compassion that had come to be reflected in the new welfare state. She further asserts that nationals constructed the welfare state as based on their own purported image of being civilized and compassionate. This compassion was played out in an ethic of caring and saving and inaugurated changes to the role of white women in the nation. The feminized values of caring and compassion came to embody a new social order and role of white women social workers (Thobani, 2007).

Thus the new roles of many white women (and white male social workers) under welfare statism played a crucial part in moving the abstract national narrative into the day-to-day lived reality and practice of "caring” and "compassion”. White women social workers who participated in the placement of Aboriginal children in residential schools and later by apprehending them into the care of child welfare agencies, "concretized and harnessed within a moral economy as very particular qualities and characteristics” (Thobani, 2007, p. 9) of being kind and caring - ostensibly by saving Indian children from their deficient and impaired Aboriginal mothers. By apprehending Aboriginal children, white women social workers exalted themselves as the very essence of the national subject as civilized and triumphantly benevolent and caring. The full force of these women's subjectivities points to such workings of identities to be a technique of power that "naturalizes itself and appears guileless, unexceptionally and ordinarily reflecting an ethical polity that is based on the inherently superior qualities of national subjects and not on the repertoire of governance” (Thobani, 2007, p. 9). In this dialectic manner, white women social workers thus emerged as the exalted national subject, and concomitantly obscured the state's role in the ongoing legacy of colonialism, white supremacy and racism that underpinned the cultural genocide of Indigenous people. The post-war welfare state now offered white women access to the emergent labour market as social workers, while fashioning for these white women a novel "experience of 'belonging' to the community through the recognition and cultivation of such shared nationality" (Thobani, 2007, p. 9). This phenomenon strengthened the bonds of the imagined community between white women and their exalted, white, male counterparts.

Concurrently, it is important not to rely on modernist binaries such as white/nonwhite, exalted/non-exalted, and white woman social worker/non-white woman social worker. Rather, postmodern and poststructural theorists have articulated well the contradictory and fluid nature of subjectivities (Weedon, 1987). Poststructuralism highlights the discursive construction of subjectivity and how individuals are formed 
through language and representation. Poststructural theories further argue that there are no essences to subjectivity but rather it is constructed precariously (Weedon, 1987) and is what Stuart Hall (1989) describes as constantly in the process of becoming. Heron (2005) points out how subjectivities are by definition always already caught up in contradictory discourses and desires. Moreover, individuals regularly take up identifications with complete contradictory subject positions made available through discourses (Heron, 2005). In light of these poststructural insights, it is important to acknowledge that white women employed as social workers in child welfare agencies are, indeed, active subjects and not wholly innocent or thoughtless tools of the state, who mindlessly reproduce discourses of white supremacy and anti-Black racism. Rather, we acknowledge the contradictory, complex, even ambivalent subjectivity of male and female child welfare workers as they negotiate the tensions between helping/empowering and oppressing families.

Similarly, we acknowledge that the non-white women and men employed in child protection agencies participate in and benefit from the economy of child welfare. We note that non-white child welfare workers thus have a certain access to and belonging within the nation state that is afforded to them through participation in the day-to-day functioning of child welfare agencies, including the apprehension of Aboriginal and nonwhite children. As such, we embrace poststructural notions of power that view it as diffuse, choatic, contradictory, multidirectional, fragmented, and implicated in knowledge/discourse. Power, then, is not held in particular bodies that are regarded as white, Black, or Asian etc., but rather in language and representation, or what Foucault (1980) calls discourses. Our view of subjectivity embraces the Foucauldian notion of the dual meaning of the subject. As Prado (2000) articulates, Foucault viewed the subject as being subjected to rule such as government; but that people are also active participants or subjects in the making of who they are. Thus the meaning of subjectivity includes both of these conscious and unconscious aspects of being a subject. For the non-white child welfare worker, this definition alerts us to how their subjectivities can be full of desires and struggles to help families, whilst also being ambivalent, even desirous for exaltation in the workplace as a competent and efficient worker. Such subjectivity recalls Du Bois' (1994) concept of double consciousness, which referred to the tremendous ambivalence felt by African-Americans, who knew what it meant and felt like to be Black in a racist society.

The vastly complex and contradictory nature of the national narrative of kindness and compassion and social worker subjectivities highlight the entrenched nature of the economy of child welfare. To be sure, not just white people benefit from this economy and this exalted national status, but rather non-white social workers can also desire, aspire, and participate in making claims to the nation via the helping and caring nature of social work.

\section{The Political Economy of Child Welfare}

The exalted status of white women social workers in the post-war national narrative has given rise to what Sinclair (2009) asserts is now a firmly entrenched 
International Journal of Child, Youth and Family Studies (2011) 3 \& 4: 385-409

economic system that rests upon the Aboriginal child welfare system. Mandell et al. (2007) point out that today there are three times as many Aboriginal children in care as compared to the height of the era of Indian residential schools. In Ontario, which entered what Strega and Esquao (2009) call the risk assessment period between 1998-1999 to 2003-2004, the number of apprehensions increased by 65\% from 11,609 to 19,105 (Dumbrill, 2006). Parada (2004) notes that during this period, due to escalating numbers of apprehensions, some welfare agencies in Ontario had to greatly expand the sizes of their workforce and offices. Indeed, the cost of child welfare in Ontario during the risk assessment period increased 100\%, from \$542 million to \$1.085 billion (Dumbrill, 2006).

To be sure, the labour sector of child welfare services in Canada is strikingly and unquestionably the domain of primarily white women. Fallon, MacLaurin, Trocmé, and Felstiner (2003) point out that $94 \%$ of child welfare workers are white; $80 \%$ are female; 97\% have English as their primary language; 70\% are between the ages of 26 and 44; and only $2 \%$ are Indigenous. Undoubtedly, a vast array of employment, wealth, and resources in Canada is now implicated in the economy of child welfare.

Reminiscent of the deadly federal funding of Indian residential schools that paid churches on a per capita basis, today's funding structures continue to reward the apprehension of children. Strega and Esquoa (2009) explain:

Present efforts to support Indigenous child welfare agencies are doomed to failure because the policy context is one of continuing to control and monitor Indigenous populations through funding formulas that privilege child protection over prevention, family preservation and support. For example, federal funding forumulas for First Nations and Indigenous agencies primarily provide funding solely for the apprehension of children rather than supportive or preventive work with families. (p. 22)

In the final section below, we argue that the overwhelming economy of the child welfare system requires significant shifts in our theorizing around racial disproportionality. We propose jettisoning anti-oppression perspectives in favour of critical race feminism and anti-colonialism. In comparison to anti-oppression, these two approaches are better equipped to address white supremacy, anti-Black, and anti-Native racism in child welfare.

\section{Theoretical Approaches to Social Work and Child Welfare Practice}

\section{Anti-Racism}

Anti-racism education is a political practice and theoretical framework that informs critical scholarly work, pedagogical, curricular, and organizational change measures, as well as social work practice. In contrast to multicultural initiatives which have been largely concerned with celebrating differences and addressing racial intolerance and inequality via attitudinal changes, cultural awareness approaches, and song-and-dance-oriented initiatives, anti-racist educators emphasize the need to battle racism on a structural, (Dei, 1996, 2008; Niemonen, 2007; Troyna, 1987), cultural, 
economic, and spiritual (Dei, 2008) level. George Dei (1996) has defined anti-racism as an "action-oriented strategy for institutional, systemic change to address racism and the interlocking systems of social oppression” (p. 25). Anti-racism uses race as the main prism through which to understand and respond to interlocking systems of oppression (Dei, 1996). Dei (2008, p. 89) maintains that while it is important to grapple with intersectionality, race must serve as the "entry point" or "lens" through which one acquires insight into inequalities of class, gender, ability, and sexuality and how these sources of oppression interact with race. Anti-racism education highlights the need to recognize race and difference as matters of power and equity and the historical context of colonialism, particularly in settler societies such as Canada (Dei, 1996, 2008). Antiracism also emphasizes self-reflexivity and the significance of whiteness, including white privilege (Dei, 2008). Social justice from an anti-racist perspective, then, entails battling both institutionalized and micro-level forms of racism in order to achieve the ideals of equality and equity.

"Integrative anti-racism" is a framework that has emerged in the last decade that stresses the imperative to work "with the intersections of race, class, gender, ability and sexuality in ways that highlight the saliency of race in critical antiracist practice” (Dei, 2008, p. 81). Hence, Dei emphasizes the need for coalition-building among traditionally marginalized statuses such as race, class, gender, sexuality, language, age, disability, and religion. Integrative anti-racism recognizes that it is impossible to grasp fully the impact of racism without understanding the ways in which it intersects and interlocks with other forms of oppression. Even within an integrative anti-racism framework, however, race remains the analytic entrance through which we understand issues of inequality and oppression (Dei, 2008).

\section{Critiques of Anti-Racism}

In the 1990s the anti-racism perspective was critiqued on a number of grounds. One criticism has centred on the tendency of some anti-racist scholarship to gesture toward bounded and recognizable racialized cultures in which intra-group divisions, ruptures, and contradictions are suppressed. It is argued that this appeal to binary racialized groupings has the effect of reinforcing essentialized (and stigmatized) categories, thereby reifying the binary it has always aimed to critique (e.g., Gilroy, 1993; Gosine, 2002; Hall, 1996; Niemonen, 2007; Yon, 2000). Pon (2000) and Yon (2000) have attributed this binary thinking to an often oversimplified conception of power within anti-racist discourse. According to Yon (2000), anti-racist education often conceptualizes power as a "zero-sum" phenomenon. The implication of this conceptualization is that there exists a finite or limited amount of power in society for which individuals and groups compete. The majority group is seen as possessing a disproportionate share of the power, while minority groups compete for what little remains. Pon (2000, p. 141) asserts the need for anti-racism discourses to utilize a Foucauldian conception of power in which power is conceptualized as "diffuse, chaotic, contradictory and multidirectional." A more complex conceptualization of power would position anti-racism to better understand the complexities and contradictions of lived experiences, and more effectively combat racism and racial inequality (Pon, 2000; Yon, 2000). 
More recently, anti-racism has been critiqued by Lawrence and Dua (2005) for overlooking the complicity of people of colour in the ongoing project of colonization by occupying and owning land that has been appropriated from Aboriginal people. Lawrence and Dua also critique anti-racism for often failing to acknowledge that in settler societies such as Canada, people of colour have rights and privileges that Aboriginal people do not have. Similarly, anti-racism often regards modernity as beginning with slavery, whereas Lawrence and Dua assert that the colonization and genocide of Indigenous peoples around the world more accurately signals the start of the modern era.

Finally, with its emphasis on race as the focal point of analyses of oppression and inequality, anti-racism has been accused of being a reductionist framework that creates a hierarchy of oppressions (McLaughlin, 2005; Williams, 1999). As Williams (1999, p. 214) notes: "Single standpoint politics have the potential to create hierarchies of oppressions in which groups eschew their points of commonality for open competition and thus become unproductive to the achievement of equality” (see also Barnoff \& Moffatt, 2007). McLaughlin (2005) asserts that proponents of anti-racism such as Lena Dominelli (1988; 1996) shifted from anti-racism to anti-oppression to avoid any appearance of ranking oppressions. According to McLaughlin, a perceived need to move from the emphasis on race to a wider and more inclusive range of interconnected oppressions underpinned the gradual shift from anti-racism to anti-oppression in Canada and the United Kingdom.

\section{Anti-Oppression Perspectives in Social Work}

In light of the criticisms leveled against anti-racism, anti-oppression perspectives have, over the course of the 1990s, emerged as a social justice approach informing social work practice, including child welfare (Baines, 2007; Carniol, 2010; Mullaly, 2002; Shera, 2003; Williams, 1999). In the new millenium some child welfare agencies in Ontario have developed or are in the process of developing anti-oppression policies (Child Welfare Anti-Oppression Roundtable, 2009). Like anti-racism, anti-oppression is an approach to social work practice that is informed by an array of critical perspectives including anti-racism, feminism, Marxism, structuralism, postmodernism, and poststructuralism (McLaughlin, 2005; Sakamoto \& Pitner, 2005). Anti-oppression perspectives advocate the critique and eradication of systemic forms of privilege, power, and oppression as generated by such social differences as class, race, gender, sexual orientation, and dis/ability (Carniol, 2010). The rising influence of anti-oppression perspectives has been facilitated by postmodern and poststructural theory (McLaughlin, 2005). Postmodern and poststructuralist influences are evident in anti-oppression's emphasis on multiple and intersecting identities (competing narratives rather than grand narratives) and the fluidity of power (its recognition that we all have identities that marginalize us alongside identities that privilege us).

There are four widely acknowledged tenets of anti-oppression perspectives: power-sharing, reflexivity, combining the micro and macro pictures, and an emphasis on multiple and interlocking identities and oppressions. Power-sharing entails creating egalitarian relationships with clients, that is, taking a "one-down" position when working with service users and treating them as experts on their own life situation (Dumbrill, 
2003; Sakamoto \& Pitner, 2005). The notion of power-sharing encompasses further the idea of creating democratic agencies and organizations where service users play a key role in programming and making administrative decisions (Dumbrill, 2003; Strier \& Binyamin, 2010). Anti-oppression perspectives emphasize also the need for selfreflexivity on the part of services providers (Strier \& Binyamin, 2010). Self-reflexivity demands of practitioners an ongoing consideration of how values, biases, social differences, and power relations affect their relationships with service users as well as interactions between service users and the organization (Strier \& Binyamin, 2010). Power-sharing and self-reflexivity represent strategies to mitigate the degree to which social service organizations might mirror and reproduce the power imbalances and inequities that exist within society at large (Strier \& Binyamin, 2010).

Borrowing from critical feminist analyses and sociological theory, the third pillar of anti-oppression perspectives has to do with situating people's narratives and challenges within a wider social and political context (i.e., helping service users to develop a critical awareness of the links between their personal issues and broader public phenomena). Finally, a central tenet of anti-oppression entails analysis of the ways in which different identities intersect and interlock in people's lives to produce marginalization as well as privilege (Sakamoto \& Pitner, 2005). Unlike anti-racism which uses race as a central analytic lens when analyzing interlocking systems of oppression, anti-oppression perspectives do not privilege any one identity or social status. Antioppression scholars and practitioners therefore consider the multiple and varied ways in which different identities intersect within the lives of individuals to shape their lived experiences and life chances. According to anti-oppression proponents, this poststructuralist emphasis on intersectionality enables anti-oppression perspectives to be more inclusive by targeting multiple oppressions while avoiding the racial emphasis frequently attributed to anti-racism (McLaughlin, 2005; Sakamoto \& Pitner, 2005).

While anti-oppression perspectives are increasingly more accepted within the social service realms, it has faced several criticisms. Five criticisms in particular have been leveled against anti-oppression perspectives. First, anti-oppression perspectives, like anti-racism, have been critiqued for gesturing toward oppositional discourses (e.g., oppression/emancipation, masculinity/femininity) that have the effect of reifying the very power imbalances anti-oppression perspectives are attempting to dismantle (McLaughlin, 2005). McLaughlin (2005) notes that this observation has been made primarily by postmodern and poststructural scholars, an irony given that these theoretical schools of thought underpin much of anti-oppression theory.

Second, critics have expressed reservations concerning the generally pronounced anti-oppression emphasis on intersectionality (e.g., Collins, 2000; Dei, 2008; Razack, 2002). Scholars assert that highlighting heterogeneity and complexity can make differences seem impossible to bridge thereby complicating the task of developing coalitions and inter-group critical consciousness. Put differently, the perspective can render people who have been subjected to various forms of oppression so seemingly disparate that the task of coalition building across differences appears almost impossible. 
A third concern with anti-oppression perspectives argues that with the emphasis on multiple identities and oppressions, it becomes easy to avoid naming and talking about the impact of racism while appearing progressive (Pon \& Phillips, 2009; Razack, 2002; Williams, 1999). In other words, there is concern that anti-oppression perspectives provide a discourse by which people can avoid naming and grappling with the difficult and volatile topics of racism and white privilege. Henry and Tator (2010) assert that racism remains one of the most volatile social issues in Canadian society.

The argument has also been made that anti-oppression perspectives, over the years in Canada and the United Kingdom, have gradually become somewhat diluted or mainstream while being co-opted by the state. McLaughlin (2005) has made the case that the capability of anti-oppression perspectives to challenge the state has receded; antioppression approaches have instead "allowed the state to reposition itself once again as a benign provider of welfare” (p. 283). As discussed above, it is quite widely argued that the anti-oppression emphasis on heterogeneity and complexity has challenged the capacity of traditionally oppressed groups to overcome their differences and develop an overarching shared critical consciousness (Collins, 2000; Dei, 2008; Williams, 1999). Given this somewhat weakened state of agency on the part of oppressed groups, the state and social workers have increasingly come to be seen as the key agents for addressing oppression and inequality. In this way, the state has come to be viewed as the "flawed but ultimately favourable referee, adjudicating between competing identity claims" (McLaughlin, 2005, p. 299). Hence, via the anti-oppression social worker, the state is able to "enforce new moral codes of behaviour on the recipients of welfare" (McLaughlin, 2005, p. 283). In this climate, anti-oppression social workers have gradually come to take on the role of policing rather than empowering service users. Moreover, the challenges service users face are divorced from structural contexts and increasingly viewed as the moral failings of individuals (McLaughlin, 2005). This latter point, insofar as it is true in the U.K. as well as other contexts, would be a particularly ironic development given that the structural contextualization of people's problems has been a central emphasis of anti-oppression perspectives.

Finally, some critics have drawn attention to the rationalist and modernist underpinnings of critical theories such as anti-racism and anti-oppression that promote self-reflexivity. They argue that because knowledge or self-awareness of bias does not necessarily bring about changes in behaviour, then logic-based notions of self-reflexivity and social change are often ineffective (Britzman, 2000; Ellsworth, 2005; Irving \& Moffatt, 2002). The limitations of such logic-based models of self-reflexive change processes is that it fails to theorize the irrational aspects of various forms of social violences such as racism, sexism, and homophobia. In other words, self-awareness of the fact that one's actions are discriminatory and causing others pain, does not lead one to necessarily stop being racist. Rather, the irrational passions of pleasure, jealousy, resentment, pride, and hatred that underpin different forms of social violence, including racism, transcend the logic of self-reflexivity (Ellsworth, 1989). 
International Journal of Child, Youth and Family Studies (2011) 3 \& 4: 385-409

\section{Critical Race Feminism or Feminist Anti-Racism}

An emergent body of scholarship over the past 10 years called critical race feminism or feminist anti-racism is spearheaded by Aboriginal scholars and female academics of colour in Canada. This scholarship provides some of the most important, critical, and innovative liberatory work in Canada around colonialism, racism, and white supremacy (see Razack et al., 2010). Much like anti-oppression, critical race feminism values critical self-reflexivity and power-sharing (see Lawrence \& Dua, 2005). Critical race feminism, however, offers much more powerful ways for theorizing the experiences of Indigenous and racialized women in settler societies such as Canada in comparison to anti-oppression perspectives, particularly vis-à-vis child welfare.

Critical race feminism is influenced by debates within the women's movement, feminism, and critical race theory. In Canada, critical race feminism, is not restricted to one perspective or approach but has "become a part of a movement and constellation of theoretical standpoints in North America and the world that include among others, tribal critical theory, Asian CanLit, and Latina/o critical theory” (Razack et al., 2010, p. 9). Using a critical emancipatory lens, these authors further argue, critical race feminism broadly interrogates the interlocking vectors of power and oppression and how social differences such as race and gender continue to reinscribe the "colour line" in an “ostensibly race- and gender-neutral liberal state” (pp. 9-10). With a keen focus on anticolonial praxis, critical race feminism theorizes persisting coloniality and white supremacy in settler societies such as Canada, and the particularities of racisms following the horrors of $9 / 11$.

We believe that the Aboriginal and women of colour scholars associated with critical race feminism are at the leading edge of emancipatory praxis in Canada and have much to offer social work educators and practitioners. Critical race feminism addresses many of the limitations associated with anti-oppression. For instance, Razack (2005) links the systemic sexual abuse of prisoners at Abu Ghraib to white supremacy. She brings complex understandings to the irrational aspects of social hatreds which would benefit logic-based models of self-reflexivity and anti-oppression work.

\section{Anti-Colonialism}

Anti-colonialism is another body of scholarship that is emerging in Canada. Ashcroft, Griffiths, and Tiffin (1995), Smith (1999), and Dei (2000) define anticolonialism as the political struggle and active resistance of colonized peoples against the ideology and practice of colonialism. Anti-colonialism is a social, cultural, and political stance against colonialism (Ashcroft et al., 1995; Dei, 2000; Hart, 2009; Smith, 1999). Anti-colonialism emphasizes decolonization and affirming Indigenous knowledge and culture, while establishing Indigenous control over Indigenous national territories. Anticolonialism further aims to establish educational opportunities that are "anti-colonial in their political orientation and firmly rooted in traditions of Indigenous nations” (Hart, 2009, p. 32). Anti-colonialism thus rejects Enlightenment principles such as the Cartesian duality that promotes a mind/body disconnect, and instead, emphasizes Indigenous epistemologies that value the mind/body connection and spirituality. 
International Journal of Child, Youth and Family Studies (2011) 3 \& 4: 385-409

Anti-colonialism, particularly with its emphases on decolonization and the validation of Indigenous epistemologies and ontologies, critiques the dominant research methods of Euro-westerners as implicated in the maintenance of colonialism (Lavallée, 2007). Lavellée asserts that the "development of theory through Indigenous worldviews by Indigenous researchers and the subsequent influence of policy by Indigenous people are essential” (p. 131). Decolonizing methodologies emphasize self-reflexivity and sharing decision-making power with the community being researched (Absolon \& Willett, 2005).

Anti-colonialism, like critical race feminism and anti-oppression, emphasizes critical self-reflexivity and power-sharing (Hart, 2009). In her discussion of Indigenouscentred social work, Baike (2009) asserts that "fundamentally, an Indigenous-centred social work theoretical framework is enabled by an anti-colonial perspective” (p. 47). She stresses the importance of social workers developing critical consciousness by reflecting on how they are impacted by Indigenous and Euro-western world views. Critical selfawareness, she argues, is paramount to ensure that social workers maximize their contributions to decolonization and minimize their implications in reproducing colonialism through their practices.

We assert that anti-colonialism and critical race feminism are the most effective approaches for understanding the contemporary racial disproportionality in child welfare. These two approaches, which value self-reflexivity and power-sharing, represent alternatives to anti-oppression discourses in that anti-colonialism and critical race feminism promise more effective and critical responses to racism and colonialism.

\section{Conclusion: The Need to Shift from Anti-Oppression to Critical Race Feminism and Anti-Colonialism}

Anti-oppression perspectives, insofar as they fail to grapple with the difficult issues of anti-Black and anti-Native racism and white supremacy, are increasingly becoming mainstream and thus perpetuate the political economy of child welfare. McLaughlin (2005) argued that within the U.K., anti-oppression perspectives have become watered down to the point where these approaches reinforce the role of the state as moral arbitrator and welfare provider. McLaughlin has observed the gradual shift in practice informed by anti-oppression from empowering service users to policing them. In the Canadian context, within the realm of child welfare specifically, the prevailing emphasis on the apprehension of children reflects the institutional entrenchment of the notion of the civilized and benevolent national subject as embodied largely by white female social workers tasked with policing individuals and families. This phenomenon within Canadian child welfare practice demonstrates that McLaughlin's observations regarding the evolution of anti-oppression perspectives hold true in Canada as well as the United Kingdom. Despite the increased emphasis on anti-oppressive practice over the last decade, research (e.g., Clarke, 2010; Dumbrill, 2003) continues to reveal a child welfare system characterized by a white, middle-class normativity. As we have argued, the overrepresentation of Aboriginal and Black children in out-of-home care is incomprehensible without acknowledging this exalted white normativity produced within 
the context of national formation. Thus, the inability of anti-oppressive perspectives to address racial disproportionality in an effective way is linked to the unwillingness or inability on the part of anti-oppression proponents to address, in a courageous and critical fashion, issues of white supremacy and anti-Black racism.

Due to its increasingly mainstream status, we propose jettisoning anti-oppression perspectives in favour of critical race feminism and anti-colonialism. We assert that these emergent perspectives more effectively theorize white supremacy, anti-Black and antiNative racism, and how the nation's exalted subject is inseperable from the welfare state. We contend that critical race feminism and anti-colonialism are the most critical, helpful, and effective approaches for understanding the experiences and realities of Aboriginal and women of colour and their families in Canada, particularly vis-à-vis the child welfare system.

While advocating that anti-oppression perspectives be supplanted within the field of child welfare, we argue for the retention of the values of critical self-reflexivity and power-sharing. Indeed, both concepts are central to critical race feminism and anticolonialism. For example, Aboriginal contributors to scholarship in anti-colonialism advocate for self-reflexivity and power-sharing, particularly given their emphasis on decolonization and reclaiming Indigenous ways of knowing and being. Similarly, Lawrence and Dua (2005) demonstrate in their scholarly work how self-reflexivity and identifying one's own subject location is paramount for understanding anti-racism and anti-colonialism. Thus, self-reflexivity and power-sharing are not the exclusive conceptual domains of anti-oppresssion perspectives. Rather anti-oppression is heavily indebted to the insights, struggles, and contributions of anti-racist, Black feminist, and decolonizing scholarship.

Anti-oppression discourses have lost much of their critical edge, having gradually succumbed to the forces of neoliberalism. Anti-oppressive perspectives are therefore proving increasingly ill-equipped to challenge, in a sustained and effective way, the entrenchment of racism and colonialism in child welfare. With the economy of child welfare now firmly engrained in our society (Sinclair, 2009), critical approaches such as critical race feminism and anti-colonialism are required by all individuals implicated in the trading in the lives of Aboriginal and Black children. 
International Journal of Child, Youth and Family Studies (2011) 3 \& 4: 385-409

\section{References}

Absolon, K., \& Willett, C. (2005). Putting ourselves forward: Location in Aboriginal research. In L. Brown \& S. Strega (Eds.), Research as resistance: Critical, Indigenous, \& anti-oppressive approaches (pp. 97-126). Toronto: Canadian Scholar's Press.

Ashcroft, B., Griffiths, G., \& Tiffin, H. (1995). The post-colonial studies reader: The key concepts. New York: Routledge.

Baike, G. (2009). Indigenous-centred social work: Theorizing social work way-of-being. In R. Sinclair, M. Hart, \& G. Bruyere (Eds.), Wicihitowin: Aboriginal social work in Canada (pp. 42-61). Halifax, NS: Fernwood.

Baines, D. (Ed.). (2007). Doing anti-oppressive practice: Building transformative politicized social work. Halifax, NS: Fernwood.

Banton, M. (1987). The classification of races in Europe and North America: 1700-1850. International Social Science Journal, 39(1), 45-60.

Barnoff, L., \& Moffatt, K. (2007). Contradictory tensions in anti-oppressive practice in feminist social services. Affilia: Journal of Women and Social Work, 22, 56-70.

Barth, R., Miller, J. M., Green, R. L., \& Baumgartner, J. N. (2001). Children of color in the child weflare system: Toward explaining their disproportionate involvement in comparison to their numbers in the general population. Chapel Hill, NC: University of North Carolina School of Social Work, Jordan Institute for Families.

Baskin, C. (2006). Aboriginal worldviews as challenges and possibilities in social work education. Critical Social Work, 7(2), [online journal]. Retrieved January 8, 2009, from http://

www.criticalsocialwork.com/units/socialwork/critical.nsf/982f0e5f06b5c9a28525 6d6e006cff78/536be566187cf89285257277002adb1d?OpenDocument

Blackstock, C., \& Trocmé, N. (2004). Community based child welfare for Aboriginal children: Supporting resilience through structural change. In M. Ungar (Ed.), A handbook for working with children and youth: Pathways to resilience (pp. 105120). Thousand Oaks, CA: SAGE.

Bolaria, S. B., \& Li, P. S. (1988). Racial oppression in Canada. Toronto: Garamond Press.

Britzman, D. P. (2000). Teacher education in the confusion of our times. Journal of Teacher Education, 51(3), 200-205. 
International Journal of Child, Youth and Family Studies (2011) 3 \& 4: 385-409

Carniol, B. (2010). Case critical: Social services and social justice in Canada (6th ed.). Toronto: Between the Lines.

Carrière, J. (Ed.). (2010). Aski awasi/children of the earth. Halifax, NS: Fernwood.

Chand, A. (2000). The over-representation of Black children in the child protection system: Possible causes, consequences and solutions. Child and Family Social Work, 5(1), 67-77.

Child Welfare Anti-Oppression Roundtable. (2009). Anti-oppression in child welfare: Laying the foundation for change. A discussion paper. Toronto: The Child Welfare Anti-Oppression Roundtable.

Ching, L. (1998). Yellow skin, white masks. In K. Chen (Ed.), Trajectories: Inter-Asian cultural studies (pp. 65-86). New York: Routledge.

Clarke, J. (2010). The challenges of child welfare involvement for Afro-Caribbean Canadian families in Toronto. Children and Youth Services Review, 33(2), 274283.

Collins, P. H. (2000). What's going on? Black feminist thought and the politics of postmodernism. In E. A. St. Pierre \& W. S. Pillow. (Eds.), Working the ruins: Feminist poststructural theory and methods in education (pp. 41-73). New York: Routledge.

Dei, G. S. (1996). Anti-racism education: Theory and practice. Halifax, NS: Fernwood.

Dei, G. S. (2000). Rethinking the role of Indigenous knowledges in the academy. International Journal of Inclusive Education, 4(2), 111-132.

Dei, G. S. (2008). Racists beware: Uncovering racial politics in contemporary society. New York: Sense Publishers.

Du Bois, W. E. B. (1994). The souls of Black folk. New York: Dover Publications.

Dominelli, L. (1988). Anti-racist social work. London: Macmillan.

Dominelli, L. (1996). Deprofessionalizing social work: Anti-oppressive practice, competencies and postmodernism. British Journal of Social Work, 26(2), 153175.

Dumbrill, G. (2003). Child welfare: AOP's nemisis? In W. Shera (Ed.), Emerging perspectives on anti-oppressive practice (pp. 101-119). Toronto: Canadian Scholars Press. 
International Journal of Child, Youth and Family Studies (2011) 3 \& 4: 385-409

Dumbrill, G. (2006). Ontario’s child welfare transformation: Another swing of the pendulum? Canadian Social Work Review, 23(1-2), 5-19.

Ellsworth, E. (1989). Why doesn't this feel empowering? Working through the repressive myths of critical pedagogy. Harvard Educational Review, 59(3), 297-324.

Ellsworth, E. (2005). Places of learning: Media, architecture, pedagogy. New York: RoutledgeFalmer.

Esquao, J., \& Sinclair, R. (2009). Considerations for cultural planning and Indigenous adoptions. In S. Strega \& S. A. Esquao (J. Carriere) (Eds.), Walking this path together: Anti-racist and anti-oppressive child welfare practice (pp. 257-272). Halifax, NS: Fernwood.

Fallon, B., MacLaurin, B., Trocmé, N., \& Felstiner, C. (2003). A national profile of child protection workers. In K. Kufeldt, \& B. McKenzie (Eds.), Child welfare: Connecting research, policy, and practice (pp. 41-52). Waterloo, ON: Wilfrid Laurier University Press.

Farris-Manning, C., \& Zandstra, M. (2003). Children in care in Canada: A summary of current issues and trends with recommendations for future research. Position paper. Ottawa: Child Welfare League of Canada.

Foucault, M. (1980). Power/knowledge. Brighton, UK: Harvester Press.

Galabuzi, G. E. (2006). Canada's economic apartheid: The social exclusion of racialized groups in the new century. Toronto: Canadian Scholars’ Press.

Gates, H. L. (Ed.). (1986). Race, writing, and difference. Chicago: University of Chicago Press.

Gilman, S. (1986). Black bodies, white bodies. In H. L. Gates, Jr., (Ed.), Race, writing, and difference (pp. 223-261). Chicago: University of Chicago Press.

Gilroy, P. (1993). The Black Atlantic. Cambridge, MA: Harvard University Press.

Goldberg, D. T. (1993). Racist culture. Cambridge, MA: Blackwell Press.

Gosine, K. (2002). Essentialism versus complexity: Conceptions of racial identity construction in education scholarship. Canadian Journal of Education, 27(1), 81-99.

Gosine, K., \& Pon, G. (2010). On the front lines: The voices and experiences of racialized child welfare workers in Ontario. Paper presented at the Annual Meeting of the Canadian Sociological Association, Montreal, QC. 
International Journal of Child, Youth and Family Studies (2011) 3 \& 4: 385-409

Haig-Brown, C. (1988). Resistance and renewal: Surviving the Indian residential school. Vancouver: Tillicum Library.

Hall, S. (1989). Cultural identity and cinematic representation. Framework, 36: 69-81.

Hall, S. (1996). New ethnicities. In D. Morley \& K. Chen (Eds.), Stuart Hall: Critical dialogues in cultural studies (pp. 441-449). New York: Routledge.

Hall, S. (2007). The rest and the west: Discourse and power. In T. Das Gupta, C. E. James, R. C. A. Maaka, G. Galabuzi, \& C. Andersen (Eds.), Race and racialization: Essential readings (pp. 56-60). Toronto: Canadian Scholar’s Press.

Hart, M. (2009). Anti-colonial Indigenous social work: Reflections on an Aboriginal approach. In R. Sinclair, M. Hart, \& G. Bruyere (Eds.), Wicihitowin: Aboriginal social work in Canada (pp. 25-41). Halifax, NS: Fernwood.

Henry, F., \& Tator, C. (2010). The colour of democracy: Racism in Canadian society (4th ed.). Toronto: Nelson Education.

Heron, B. (2005). Self-reflection in critical social work practice: Subjectivity and the possibilities of resistance. Reflective Practice, 6(3), 341-351.

Irving, A. \& Moffatt, K. (2002). Intoxicated midnight and carnival classrooms: The professor as poet. Radical Pedagogy, 4(1).

James, C. E., Este, D., Bernard, W. T., Benjamin, A., Lloyd, B., \& Turner, T. (2010). Race and well being: The lives, hopes, and activism of African Canadians. Halifax, NS: Fernwood Publishing.

Lavallée, L. (2007). Physical activity and healing through the medicine wheel. Pimatisiwin: Journal of Aboriginal and Indigenous Health, 5(1), 127-153.

Lawrence, B., \& Dua, E. (2005). Decolonizing anti-racism. Social Justice, 32(4), 120143.

Lowe, L. (1996). Immigrant acts: On Asian American cultural politics. Durham, NC: Duke University Press.

Maiter, S. (2009). Race matters: Social justice not assimilation or cultural competence. In S. Strega \& S. A. Esquao (J. Carrièrre) (Eds.), Walking this path together: Antiracist and anti-oppressive child welfare practice (pp. 62-77). Halifax, NS: Fernwood Publishing.

Mandell, D., Clouston Carlson, J., Fine, M., \& Blackstock, C. (2007). Indigenous child welfare. In G. Cameron and N. Coady (Eds.), Moving towards positive systems of child and family welfare (pp. 115-159). Waterloo, ON: Wilfrid Laurier Press. 
International Journal of Child, Youth and Family Studies (2011) 3 \& 4: 385-409

McLaughlin, K. (2005). From ridicule to institutionalization: Anti-oppression, the state and social work. Critical Social Policy, 25(3), 283-305.

Monture, P. (1995). Thunder in my soul: A Mohawk woman speaks. Halifax, NS: Fernwood.

Mullaly, B. (2002). Challenging oppression: A critical approach to social work. Toronto: Oxford University Press.

Niemonen, J. (2007). Antiracist education in theory and practice: A critical assessment. The American Sociologist, 38(2), 159-177.

Ng, R. (1993). Racism, sexism, and nation building in Canada. In C. McCarthy \& W. Crichlow (Eds.), Race, identity, and representation in education (pp. 50-59). New York: Routledge.

Ontario Association of Children's Aid Societies. (2008). Child in care fact sheets as at March 31, 2008.

Parada, H. (2004). Social work practices within the restructured child welfare system in Ontario: An institutional ethnography. Canadian Social Work Review, 21(1), 67-86.

Pon, G. (2000). The art of war or the wedding banquet? Asian Canadians, masculinity and anti-racism education. Canadian Journal of Education, 25(2), 139-151.

Pon, G., \& Phillips, D. (2009). Fear, anti-oppression, and child welfare: The dialectic of race and fear. Paper presented at the Annual Conference of the Canadian Association of Social Work Educators, Ottawa, ON.

Prado, C. G. (2000). Starting with Foucault: An introduction to genealogy. Boulder, CO: Westview Press.

Razack, N. (2002). Transforming the field: Critical antiracist and anti-oppressive perspectives for the human services practicum. Halifax, NS: Fernwood.

Razack, S. (2005). How is white supremacy embodied? Sexualized racial violence at Abu Ghraib. Canadian Journal of Women and the Law, 17(2), 341-363.

Razack, S., Smith, M., \& Thobani, S. (Eds.). (2010). States of race: Critical race feminism for the $21^{\text {st }}$ century. Toronto: Between the Lines.

Roberts, D. (2002). Shattered bonds: The color of child welfare. New York: Civitas Books. 
International Journal of Child, Youth and Family Studies (2011) 3 \& 4: 385-409

Sakamoto, I., \& Pitner, R. O. (2005). Critical consciousness in anti-oppressive social work practice: Disentangling power dynamics at personal and structural levels. British Journal of Social Work, 35(4), 435-452.

Shera, W. (Ed.). (2003). Emerging perspectives on anti-oppressive practice. Toronto: Canadian Scholar's Press.

Sinclair, R. (2009). Identity or racism? Aboriginal transracial adoption. In R. Sinclair, M. Hart, \& G. Bruyere (Eds.), Wicihitowin: Aboriginal social work in Canada (pp. 89-113). Halifax, NS: Fernwood.

Smith, L. T. (1999). Decolonizing methodologies: Research and Indigenous peoples. New York: Zed Books.

Strega, S. (2007). Anti-oppressive practice in child welfare. In D. Baines (Ed.), Doing anti-oppressive practice (pp. 67-82). Halifax, NS: Fernwood.

Strega, S., \& Esquao, S. A. (Carrière, J.). (Eds.). (2009). Walking this path together: Antiracist and anti-oppressive child welfare practice. Halifax, NS: Fernwood.

Strier, R., \& Binyamin, S. (2010). Developing anti-oppressive services for the poor: A theoretical and organizational rationale. British Journal of Social Work, 40(6), 1908-1926.

Thobani, S. (2007). Exalted subjects: Studies in the making of race and nation in Canada. Toronto: University of Toronto Press.

Tilbury, C., \& Thoburn, J. (2009). Using racial disporportionality and disparity indicators to measure child welfare outcomes. Children and Youth Services Review, 31(10), 1101-1106.

Trocmé, N., Knoke, D., \& Blackstock, C. (2004). Pathways to the overrepresentation of Aboriginal children in Canada's child welfare system. Social Service Review, 78(4), 577-600.

Troyna, B. (1987). Beyond multiculturalism: Towards the enactment of anti-racist education in policy provision and pedagogy. Oxford Review of Education, 13(3), 307-320.

Weaver, H. (1999). Indigenous people and the social work profession: Defining culturally competent services. Social Work, 44(3), 217-225.

Weedon, C. (1987). Feminist practice and poststructuralist theory. Oxford, UK: Blackwell. 
International Journal of Child, Youth and Family Studies (2011) 3 \& 4: 385-409

Williams, C. (1999). Connecting anti-racist and anti-oppressive theory and practice. Retrenchment or reappraisal? British Journal of Social Work, 29(2), 211-230.

Yon, D. (2000). Elusive culture: Schooling, race, and identity in global times. New York: State University of New York Press.

\section{Endnotes}

\footnotetext{
${ }^{i}$ We use the term "mainstream" to refer to social work perspectives and/or social work agencies whose ways of knowing, policies, procedures and practices are primarly grounded in the maintenance and reproduction of the status quo (settler society), while offering individuals opportunities for career advancement and self-gain. Baines (2007) describes mainstream social service agencies as hierarchical entities that are not so much concerned with progressive social transformation, but rather locating social problems within the individual and/or family, and thereby maintaining the status quo.

ii Like Sinclair (2009), we use the term “Aboriginal,” "Indigenous,” and "Native” interchangeably to refer to individuals who self-identify as the original peoples of Turtle Island including the Métis and Inuit. As non-Aboriginals, we recognize the dangers of using these terms in ways which Sinclair (2009) calls a colonial process of homogenizing Indigenous people despite the vast array of diversity and heterogeneity amongst Indigenous peoples.
} 